\title{
INSTITUTIONAL DETERMINANTS OF MILITARY SPENDING
}

Daniel Albalate, Germà Bel and Ferran Elias

\begin{abstract}
Drawing on a database for 1988-2006 containing information on 157 countries, we investigate the effects on military spending of government form and democracy, electoral rules and concentration of parliamentary parties. From an OLS regression on pooled data, our results show that presidential democracies spend more than parliamentary systems on defense, whereas its interaction with a majoritarian electoral rule reduces the defense burden. Our findings suggest that, in contrast to theoretical predictions in the literature, institutions do not have the same impact on the provision of all public goods.
\end{abstract}

Keywords: Military Spending; Politics; Institutions

JEL Codes: H11, H41, H56. 


\section{INSTITUTIONAL DETERMINANTS OF MILITARY SPENDING}

\section{Introduction}

Understanding the determinants of defense burdens has important ramifications as military spending is a key issue in post-conflict situations, potentially undermining the economic growth of poor and corrupt countries. Further, the vicious circles that can be formed by military spending, economic growth and conflict make it even more important that these determinants be understood.

Marked differences exist in defense burdens across countries and over time. The difficulty in accounting for military expenditure lies in the fact that many factors have to be taken into consideration: threats posed by other countries or internal rebellion, membership of an alliance, population, wealth and the characteristics of the political system.

The empirical literature examining these issues (Rosh, 1988; Dunne \& Perlo-Freeman, 2003a, 2003b, Dunne et al., 2008; Gadea et al., 2004; Yildirim, J. \& S. Sezgin, 2005; Collier \& Hoeffler, 2007; Nikolaidou, 2008) has shed some light on our overall understanding of military spending. Yet, there are a number of areas that need to be explored which might further this knowledge, but they have received little consideration to date. Principally, the range of political regimes considered in the existing empirical literature is somewhat narrow with most studies adopting various measures of democracy as an explanatory variable of military expenditure, and all concluding that democracies spend less than autocracies do on defense.

However, no distinction is made regarding the specific systems adopted in these democracies, which far from being one-dimensional categories are better considered in terms of their multi-dimensionality. ${ }^{1}$ Indeed, constitutions provide for presidential and parliamentary democracies, establish plural and proportional electoral rules, among many

\footnotetext{
${ }^{1}$ This approach is based on Persson, Roland \& Tabellini (1997 and 2000) and Persson \& Tabellini (1999 and 2003), who have made a considerable contribution to the literature on economics and political science by studying the link between constitutional systems and economic policy.
} 
other factors. As such, regime type - seen as much more than the simple distinction between democracy and autocracy - defines the structure of incentives in which agents take their decisions. And so, there may well be a relationship between the different dimensions of democracy and military spending that has not, to the best of our knowledge, been studied yet.

A number of theoretical studies have in fact stressed the importance of identifying the specific traits of each democracy. Persson, Roland \& Tabellini (2000), henceforth PRT, predict that there tends to be an underprovision of public goods in presidential democracies under systems of plurality rule, ${ }^{2}$ which leads us to assume that there would be a negative relationship between presidential democracies and military spending. Note, however, that military spending could not be a public good for the population, but a rather private good for the ruling class (Besley \& Persson 2008a, 2008b, 2010). Because of this, even in a democracy military spending could be used to foster reelection.

A number of political science studies suggest just that presidential systems are more prone to civil conflict than are parliamentary democracies because of a lack of flexibility and the dual legitimacy ${ }^{3}$ that arises from the election of both president and parliament (Linz 1990, 1994). Reynal-Querol (2005) analyzed the relation between political systems and civil conflict and found that less inclusive systems -for example, presidential regimes- are more prone to civil war. Were this to be the case, it could be argued that a relation might exist between proneness to conflict and military expenditure. Indeed, this is consistent with Besley \& Person (2009), which shows that states with more developed and stable institutional and

\footnotetext{
${ }^{2}$ PRT consider the main characteristic of a presidential democracy to be the separation of proposal powers within the legislature. Basically, the direct election of the executive does not provide any incentives for the maintenance of a stable majority to support the government. Therefore, there is no particular tendency towards legislative cohesion, which is rather a feature of parliamentary democracies. An empirical exercise has been conducted to test this prediction, but its results were much weaker than expected (Persson \& Tabellini, 1999).

${ }^{3}$ Dual legitimacy refers to the fact that, because both the president and the parliament are elected democratically, both enjoy the legitimate right to exercise their rights and powers. In case of conflict between these two institutions, there are no clear-cut constitutional means for dealing with it, which can take the conflict to a higher level.
} 
political systems are less prone to internal violence and, therefore, have fewer incentives for military spending.

According to Linz (1994), in the case of growing institutional conflict in a presidential democracy between president and parliament, no democratic principles are in place to resolve the discord. In such circumstances, the military can act as a leveraging power, giving them a role in the civil power game that enhances its importance in a presidential system. Thus, it seems plausible that this position of the army in presidential systems can result in higher spending. In other words, the military might be seen to be using their power and influence in a presidential system to control the state, thus securing for themselves higher rents and greater investment in the army.

In this paper we test the relation between form of government -presidential or parliamentary, electoral rules -plural or proportional, concentration of the parliamentary party groups and military spending. Our results partially contradict the theoretical prediction made in PRT (2000), since our empirical evidence on military expenditure shows that presidential democracies spend more than their parliamentary counterparts, and that countries operating majoritarian and presidential systems spend less than countries operating systems of proportional representation.

The contribution of this paper, which merges two different streams of the literature, military spending and political economy, is twofold. First, to our knowledge, it is the first multivariate estimation to include institutional characteristics as determinants of defense spending. Second, it is the first empirical study to show that in pooled data military expenditure is higher in presidential than in parliamentarian systems. These findings should serve to trigger more theoretical research that can help shed more light on the effects of different constitutions on military spending, and highlight the importance of institutional variables on military expenditure. 
The paper is organized as follows. The next section briefly discusses the importance of studying the determinants of military spending. Then we review the literature on defense burdens. Next we present the empirical strategy adopted in the paper. After completing the estimations, we discuss the results for pooled data, paying particular attention to the results following the inclusion of institutional variables in the equations. Finally, we offer our concluding remarks.

2. Military spending and wars.

The determinants of military spending need to be understood particularly because of the role played by military spending in post-conflict situations. Military expenditure might be seen as acting as a deterrent on warring parties and, as such, this expenditure would be a regional public good. Nonetheless, Collier \& Hoeffler (2006) showed that in post-conflict situations military spending increases the risk of renewed civil conflict. In their study, they show that a government's military spending acts as a signal of its intentions. To understand the underlying rationale, note that the military capability of the rebels is more significantly undermined the longer peace is maintained post-conflict, and so rebel groups lose their bargaining power in post-conflict situations. Then, although the government should negotiate a peace settlement that is acceptable to the rebels, it is likely to be rejected owing to a timeconsistency problem. In the absence of any guarantees that the government will uphold the same peace conditions despite the rebels' loss of power, military spending signals the government's intentions. High spending indicates a high probability of non-fulfillment of the peace treaty, increasing the risk of renewed conflict, and vice versa.

Therefore, money invested in the military acts as a regional public bad effect. In other words, in tense situations with a recent history of blood and strife, military spending acts as a signal of the government's commitment to peace. Having said this, it is important to ask whether there are any particular institutional characteristics that might promote defense 
spending. That is, are there any structural elements in a political-economic system that might undermine a peace process? If so, what are these characteristics? These questions are best understood if we could identify the determinants of military spending - in particular, the institutional determinants.

Moreover, vicious circles can form involving military spending, growth and war, as suggested by works such as Collier and Hoeffler (2002), who found that, while African countries had a similar incidence of conflict as other developing countries, the risk on that continent was higher because of its economic characteristics. By contrast, Africa's social characteristics do not increase the risk of civil conflict since fractionalized societies are safer than homogenous ones as rebel groups encounter many difficulties in maintaining their cohesion. Consequently, it is the economic failure of Africa that would seem to make this continent more prone to civil war. Thus, cutting military spending is not only important for the role it plays in post-conflict situations or for the effect it has on growth in corrupt countries, but also because it would help break the vicious circle of conflict in which some countries have become trapped in recent decades.

\section{Related empirical literature}

Two types of model have been used to examine the determinants of military spending (Dunne \& Perlo-Freeman; 2003a): firstly, the arms race model (Richardson, 1960), which focuses primarily on the military spending of potential enemies or allies to explain defense spending; and secondly, models that include economic, political and strategic factors (Dunne \& PerloFreeman; 2003a, 2003b and 2008; Gadea et al., 2004; Yildirim \& Sezgin, 2005; Collier \& Hoeffler, 2007; Nikolaidou, 2008).

Arms race models based on bilateral relationships have proved unsuccessful in explaining the determinants of military expenditure (Majeski and Jones, 1981). It would seem that security is a multilateral, not a bilateral concern, as Rosh (1988) explains in developing the 
concept of a security web. Rosh argues that security is the most influential explanatory variable determining military spending and that most threats to security are posed by bordering countries. It is for this reason that policymakers in developing countries scrutinize the military budgets of countries in their geographical region. Thus, the study averages military expenditure as a percentage ${ }^{4}$ of the gross national product of the neighboring states of developing countries, along with the GNP of states in their security web, i.e., those states that might participate in a dispute beyond their immediate borders. The results reveal security webs as having the most important, significant and positive effect on military spending.

Recently, Dunne \& Perlo Freeman (2003b) found that the determinants of military spending changed after the end of the Cold War. Although Rosh (1988) showed a country's security web to be the most important factor, the main type of conflict over the last two decades has, in fact, been civil war (Harbom and Wallensteen, 2007). This suggests that the determinants of military spending have indeed changed with countries becoming less concerned with the arms race and more worried about internal strife ${ }^{5}$.

In addition to these papers that highlight the importance of security issues, a second wave of research has focused on three types of variable in order to explain military spending: socioeconomic, strategic and political variables (Dunne et al., 2003a, 2003b and 2008; Gadea et al., 2004; Yildirim \& Sezgin, 2005; Collier \& Hoeffler, 2007; Nikolaidou, 2008). The methodologies adopted in these papers differ. Thus, for example, Dunne \& Perlo-Freeman (2003a) use static and dynamic panel data analysis, Dunne \& Perlo-Freeman (2003b) use cross-country data, Dunne et al. (2008) use panel data regressions and Collier \& Hoeffler

\footnotetext{
${ }^{4}$ Dunne \& Perlo-Freeman (2003b) criticize this measure because they consider that the absolute level of military force facing a country is a better measure of the threat it faces. Therefore, they use the total level of military spending in the Security Web as an explanatory variable.

${ }^{5}$ Dunne \& Perlo-Freeman (2003b) confirm this by showing that the fall of the Berlin Wall represented a structural break. Results show that civil wars have had a significantly higher coefficient in the post-Cold War period.
} 
(2007) use a pooled data regression analysis. Although their results are largely similar, a number of discrepancies are worth noting.

Among the socioeconomic variables examined are population, national income measures, trade and external aid. Population has been shown to have a significant and negative effect (Dunne et al., 2003a, 2003b and 2008; Collier \& Hoeffler, 2007) ${ }^{6}$. Dunne \& Perlo-Freeman (2003b) offer two explanations for this. First, they consider that having a large population in itself offers security and, secondly, that larger populations might make civil consumption needs more of a priority than security needs (Dunne \& Perlo-Freeman; 2003b, pp. 31).

When using GNP as a measure of national income, Dunne et al. (2003a, 2003b and 2008) reported it to be insignificant (Dunne \& Perlo-Freeman, 2003a and 2003b), while Dunne et al. (2008) found it to have a significant and negative effect on military expenditure. By contrast, Collier \& Hoeffler (2007) use GDP per capita as their measure and found it to be significant and positive. According to these authors, this finding reflects the fact that a state's capacity to tax and borrow increases with development.

Trade has a positive and significant effect in a dynamic panel specification that takes into account the Cold War and post-Cold War years, whereas in the static fixed effects model it is also significant but its sign is negative (Dunne \& Perlo-Freeman, 2003a).

In Collier \& Hoeffler (2007) the relationship between development aid and military expenditure is examined. The authors were concerned that aid might in fact be financing military spending. Their results show that aid has a significant and positive effect on military expenditure and that, on average, $11.4 \%$ of development aid leaks into defense budgets.

Studies examining strategic variables have looked at external wars, civil wars, security webs, external threats, internal threats, potential enemies and regional dummies. The external and civil war variables seek to capture a country's participation in war. Most studies use data

\footnotetext{
${ }^{6}$ This result holds except in the dynamic panel estimation and for the Cold War period estimation under fixed effects (Dunne \& Perlo-Freeman, 2003a)
} 
for pre- and post-Cold War periods and include both variables, showing a significant and positive effect on military spending. External war is defined as a dummy variable that takes a value of 1 when a country is involved in an international war. Results show that it increases military spending (Dunne \& Perlo-Freeman, 2003a, 2003b and 2008; Collier \& Hoeffler, 2007). Civil war is characterized as an index variable that ranks from 0 to 4 (Dunne \& PerloFreeman, 2003a, 2003b and 2008) and as a dummy that takes a value of 1 if a country experiences an internal conflict with at least 1000 battle-related deaths per year (Collier \& Hoeffler, 2007). However it is defined, it is significant and positive in most studies.

Some strategic variables - including the security web - seek to capture the effect on military spending of threats from other countries or opposition groups. Dunne \& PerloFreeman (2003a) adopt Rosh's definition (see above) and run a regression of military spending on it along with a potential enemy variable (identifying the countries with the greater potential for conflict within each security web) and other control variables. With static panel data, the security web is found to be insignificant while potential enemies is significant, which suggests that the greatest threats are posed by the latter. In dynamic panel regressions, both variables were significant and positive.

Dunne \& Perlo-Freeman (2003b) define their security web variable as total military spending within the web and not as an average of the states' military burdens. They claim that this definition captures the threat imposed by neighboring countries better, while the average defense burden represents the effort expended by countries in developing their armies. As in Dunne \& Perlo-Freeman (2003a), they include the potential enemies variable. In this study both are significant and positive. Collier \& Hoeffler (2007) define both a neighborhood threat and emulation variables. The threat variable is the sum of a state's neighbors' military expenditure, divided by the home country's GDP, while the emulation variable is defined in line with Rosh (1988). When both are included in the regressions, only 
the emulation variable is significant. Collier \& Hoeffler (2007) suggest that the level of threat is captured by the external and internal threat variables (see below), which would explain the non significance of the neighborhood threat variable. Thus, they chose to drop this threat variable and to maintain the emulation variable only.

Collier \& Hoeffler (2007) consider both external and internal threats. The external threat is a dummy variable that takes a value of 1 when a country has been involved in an international war after World War II. Its effect is significant and positive. By contrast, the internal threat is the predicted probability of a civil war breaking out, based on the methodology outlined in Collier \& Hoeffler (2002). Its effect is also significant and positive. Nonetheless, security environment is still a crucial factor to explain military expenditure, as shown in a recent paper by Nordhaus, Oneal and Russett (2009). These authors incorporate a comprehensive measure of the external threat, and find that ex-ante threat environment is more influential than any of several influences only known ex-post they consider.

Finally, these papers consider a number of political features, but in a somewhat limited manner as we seek to show below. Most studies include a measure for democracy when they run military spending regressions. The correlation is always significant and negative (Dunne \& Perlo-Freeman, 2003a, 2003b and 2008; Nordhaus, Oneal and Russett, 2009). Polity IV ${ }^{7}$ measures of democracy and autocracy are used. They compute the difference between the measure of democracy (from 0 to 10 , where the rising quality of democracy receives higher values) and the measure of autocracy (from 0 to 10 , where the regime is increasingly more autocratic at higher values). Thus, they obtain a measure of democracy that ranks between 10 (perfect autocracy) and 10 (perfect democracy).

Collier \& Hoeffler (2007) also consider a measure of democracy. Using the Polity IV data set, they measure the general openness of political institutions on a scale of 0 (low) to 10

\footnotetext{
${ }^{7}$ The Polity IV Project codes the authority traits of states in the world system for purposes of comparative and quantitative analysis. See Jaggers \& Gurr (1995) and http://www.systemicpeace.org/polity/polity4.htm
} 
(high). They also find a highly significant negative relationship ${ }^{8}$. Collier \& Rohner (2008) use Polity IV data as a dummy variable for democracy, and find as well that democracies are less prone to violence that autocracies. However, when they interact democracy and income, they find that democracy together with low income might actually increase violence. In an interesting and very recent work, Bove and Brauner (2011) analyze the effect of different authoritarian regimes on military expenditure. These authors distinguish between Personalist, Single party, Monarchy and Military authoritarian regimes, and find the military regimes have the highest military spending, whereas Personalist regimes have the lowest expenditure.

The democracy and autocracy scores of Polity IV (Jaggers \& Gurr, 1995) are constructed taking into account the competitiveness of political participation, the regulation of political participation, the competitiveness of executive recruitment, the openness of executive recruitment and the constraints on the chief executive. However, these measures do not allow the effect of other specific constitutional features to be examined. For example, is the military expenditure of presidential systems higher or lower than that of parliamentary systems? What effect does the electoral system have? Does the concentration of the parliamentary party groups matter in the case of defense spending? Does the political color of the government affect it? In this paper we seek to answer these and other questions.

4. Empirical strategy: sample, data and models

Our sample contains data for 157 countries for the period 1988 to 2006 . The countries considered are those for which military expenditure information exists in the SIPRI (Stockholm International Peace Research Institute) database.

The model we estimate by a pooled OLS is based on the standard models of the determinants of military defense, which include threat, emulation and socioeconomic variables, as well as the variable "democracy" (as in Dunne \& Perlo-Freeman (2003a, 2003b,

\footnotetext{
${ }^{8}$ Yildirim \& Sezgin (2005) use a different measure of democracy and investigate its relation with military spending. They found it to be negative and significant.
} 
2008), and Collier \& Hoeffler (2007). Nonetheless, we will use another alternative variable for political and civil rights, which is the freedom score, computed and provided by Freedom House since $1973 .^{9}$

Our empirical strategy is based in a two stage estimation procedure. Our first model (equation 1) to be estimated is the one in which we consider the full sample of autocracies and democracies and test the impact of democracy and freedom indicators on military spending. The second model to be estimated is an extended model in which we consider electoral rules and institutional variables such as presidential systems, majoritarian electoral rules and parliamentary concentration. This extended model is run only for democratic countries. $^{10}$

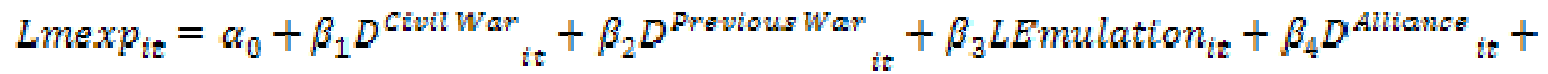

$$
\begin{aligned}
& \beta_{5} \text { LPopulation }_{i t}+\beta_{6} L G D P p c_{i t}+\beta_{7} \text { Democracy }_{i t}+\delta_{\mathrm{g}} \text { Trend }_{\mathrm{t}}+\gamma_{9} \text { Africa }_{i}+ \\
& \gamma_{10} D^{\text {Europe }}{ }_{i}+\gamma_{11} D^{\text {Asia }}{ }_{i}+\varepsilon_{i t} \\
& \text { Lmexp }_{i s}=\alpha_{0}+\beta_{1} D_{i t}^{\text {Civil War }}+\beta_{2} \text { Pravious War }_{i t}+\beta_{3} \text { LEmulation }_{i t}+\beta_{4} D^{\text {Allianes }}{ }_{i t}+ \\
& \beta_{5} \text { LPopulation }_{i t}+\beta_{6} \text { LGDPpC }_{i t}+\beta_{7} \text { Pres }_{i t}+\beta_{\mathrm{g}} \text { Majoritarian }+\beta_{9} \text { Pres } * \text { Major }_{i t}+ \\
& \beta_{10} \text { Concentration }{ }_{i t}+\delta_{10} \text { Trend }_{t}+\gamma_{11} D^{\text {Africa }}{ }_{i}+\gamma_{12} D^{\text {Europe }}{ }_{i}+\gamma_{13} D^{\text {Asia }}{ }_{i}+\varepsilon_{i t}
\end{aligned}
$$

Table 1 provides information on all variables used, the data source, and the expected effect on military expenditure. The explanatory variables can be grouped in three categories. The first category includes the threat variables: Civil war, Previous war, Emulation, and Alliance. The second includes the socioeconomic variables: Population and GDP per capita.

\footnotetext{
${ }^{9}$ We thank to an anonymous referee for leading us to this alternative variable for political and civil rights.

${ }^{10} \mathrm{We}$ consider a country as being a democracy when the Polity IV democracy score is higher than its autocracy score.
} 
These two groups are applied to each model. The focus of this paper is, however, on the role of institutional variables on military spending. For this reason we include different institutional variables in equation 1 and equation 2. On one hand, we use Democracy, and Freedom as the variables considered for the full sample estimation that includes autocratic and democratic countries. On the other, we deeply analyze the institutional and electoral rules in democracies by considering Presidential systems, voting systems, and their interaction Pres*Majoritarian in addition to the Concentration variable. Moreover, in order to capture the effects of time we include a time trend variable and to capture continental non-observable fixed effects we include dummy variables for Africa, Asia and Europe.

(Insert table 1 around here)

It is worth providing a more detailed explanation of some of the institutional variables, and, in particular, of the differences between presidential and parliamentary democracies, on the one hand, and between majoritarian and proportional voting systems, on the other. In a presidential democracy the president is elected directly by the people and as such is considered to have a direct mandate. In such a system, the legislature and the executive are separate parallel structures; this means each is free to monitor the actions of the other. In a presidential system, there is a clear-cut separation of powers between the executive and the legislative. By contrast, in a parliamentary democracy the president is elected indirectly by the legislature and there is no clear-cut separation of powers. The executive is drawn from the legislature and it is accountable to that body.

In the case of electoral systems, a majoritarian voting system is a winner-takes-all system, where the winner is the person with the most votes. Conversely, proportional representation seeks to match the percentage of votes received by each party and the proportion of seats it holds in parliament. 
Thus, it is more than apparent that such differences will affect the political process and the economic decisions taken in each country. And, consequently, there may well still be an unexplained link between constitutions and military expenditure. Our models for democracies are prepared to capture the effect of these institutional variables on military spending. Results are displayed throughout the next section.

\section{Results and discussion}

We carried out pooled OLS regressions after rejecting the fixed effects model due to lack of variation over time of key institutional variables and after applying the Breusch and Pagan Lagrangian multiplier test that rejects panel effects. Given sample constraints and results from this test against the use of the alternative random effects model we chose a pooled OLS model. ${ }^{11}$ However, we will provide estimates using panel data with country-specific fixed effects and an additional cross section estimation after collapsing information for all years available into mean variables for the whole period covered to favor discussion on fit and consistency of our results across models. This model is used for our two stages of estimation containing different sample sizes due to the fact that in the second stage we only consider democracies, while in the first we run our model on all observations available (autocracies and democracies). ${ }^{12}$ Different specifications are provided in each case, according to whether we use clusters at country level or dummy year variables instead of a trend variable. In models where clusters by country are used, we allow for an arbitrary variance-covariance

\footnotetext{
${ }^{11}$ On the basis of the results of the Hausmann test between fixed effects and random effects panel models indicated the use of the first. However, the lack of variation over time of the key variables of the analysis such as "Pres", "Majoritarian" and "Presmaj" makes impossible the use of the within estimator due to time invariant covariates. Therefore, fixed effects does not seem to be the right estimator for our analysis. The random effects model it is not only rejected by the Hausman test, but also the Breuch Pagan test for panel effects rejects its superiority over Pooled OLS.

${ }_{12}$ Missing values for some or our variables affect the final number of observations used in each of our regressions.
} 
matrix. ${ }^{13}$ Otherwise, we use the Huber-White correction of standard errors. Also we show results for cross section regressions in which we use data for 2005.

The correlation matrix is included in the Appendix (A1). In addition, variance inflation factor (VIF) tests were conducted to test the severity of multicollinearity, rejecting problems of this kind. Finally, the Breusch-Pagan test was used to confirm heteroskedasticity, what led to the use of corrected Huber-White standard errors where cluster correction was not introduced.

\subsection{The impact of Democracy and Freedom on military spending}

The results for the first stage of analysis which includes autocracies and democracies are displayed in Table 2. Different specifications are offered. Model 1 shows results for pooled OLS estimates without country clusters - but providing Huber-white corrected standard errors- and with a time trend. Model 2 includes country clustered standard errors by country. Model 3 substitutes the Democracy variable with the Freedom Variable and Model 4 includes year dummies instead of the time trend variable. Finally, Models 5 and 6 provide panel data estimates with fixed effects and a cross-section OLS estimation for mean values of variables for the whole period covered. the last year in which we have the maximum number of observations (minimization of missing values).

Regarding our institutional variables "Democracy", as well as its substitute "Freedom", we find highly statistically significant coefficients with negative sign, as expected from the literature. This implies that the military expenditure of democracies is not as big as that of autocracies. ${ }^{14}$ This result is consistent across all models presented.

\footnotetext{
${ }^{13}$ The estimator used for the variance-covariance matrix allowing for all types of correlation takes the following form: $\mathrm{V}=\left(\mathrm{X}^{\prime} \mathrm{X}\right)^{-1}\left(\Sigma_{i=1}^{N}\right.$ ui'ui $)\left(\mathrm{X}^{\prime} \mathrm{X}\right)^{-1}$ and $\mathrm{u}_{\mathrm{i}}=\Sigma_{t=1}^{T} e_{i t} x_{i}$, where $\mathrm{V}$ represents the variance-covariance estimator, $\mathrm{X}$ the matrix of independent variables, and $\mathrm{N}$ the number of groups (countries). By contrast, $\mathrm{e}_{\mathrm{it}}$ is the countryyear specific residual and $\mathrm{x}_{\mathrm{it}}$ the vector of independent variables. Because this method is only valid asymptotically, we apply the finite sample adjustment used by STATA package: $\mathrm{N}-1 /(\mathrm{N}-\mathrm{k}) * \mathrm{M} /(\mathrm{M}-1)$, where $\mathrm{N}$ is the number of observations, $\mathrm{k}$ the number of regressors including the constant, and $\mathrm{M}$ the number of clusters.

${ }^{14}$ In our sample the average share of military spending on total public expenditure is $10 \%$. However, democracies present a lower mean percentage of $7 \%$ and autocracies an average of $18 \%$.
} 
The threat variables were "Civil war" and "Previous war". Civil war is significant at the $1 \%$ or $5 \%$ level of probability across models and presented a positive sign as expected. Previous war, which captures tensions between and within countries, is not statistical significant in our models, suggesting that a past marked by conflict does not exert enough pressure on defense spending over time according to our results.

(Insert table 2 around here)

The "Alliance" variable is significant across models and reports a positive and statistically significant coefficient, indicating that when a country forms part of an alliance, military spending increases. Note that this is the first time this variable has been defined in terms of whether a country belongs to NATO or the Warsaw Pact. It might be thought that being a member of a collective defense system would lead to a reduction in military spending given that as all the member states are committed to their mutual defense in response to an attack by an external party, there would be relatively few threats from other countries and that when these came they would not be very challenging. However, our results show this hypothesis not to hold. The reason for this is that member countries are committed to maintaining a given level of defense spending.

The "Emulation" variable does not appear to be statistically significant, implying that if the mean defense burden of your neighbors is higher than your own, your military spending will not necessary increase to a similar level according to these results.

The socioeconomic variables were "Population" and "GDP per capita". The impact of these variables is sensitive to the specification used. Both are statistically significant without clusters, and their inclusion diminishes the precision of their impact. In both cases, when statistically significant, they increase military spending, being this consistent to the results in Collier \& Hoeffler (2007). 
We also considered continental dummies for Africa, Europe and Asia. Africa and Asia appears to be significant across models. The positive consistent impact of regional dummies linked to these regions indicate that military spending is larger in Africa and Asia than that of the comparison group of countries in America.

The trend variable and year dummies also offer interesting results. The negative impact shown by its coefficient indicates that military spending falls slightly each year. This result might capture the effects of the end of the Cold War since the sample data were first collected for 1988. To make a deeper analysis of this result we included year dummies in Model 4 that indicate that this fall started in the mid 90's respect to the military spending in the 80's what seems to indicate to the consequences of the end of the Cold war.

Finally, note that the use of panel data with country-specific fixed effects (Model 5) or cross sectional models that do not consider the time dimension of the sample (Model 6) seem to provide similar results, supporting the robustness of the analysis across estimation strategies.

\subsection{The impact of Institutional variables and Electoral rules on military spending}

We are now in a position to broaden the analysis by examining the effect of different political systems given that they are not one-dimensional, but rather they present a range of different dimensions that can have a varied effect on military expenditure. The "Democracy" of "Freedom" variables do capture certain dimensions, but not such features as the form of government or the electoral system. Thus the impact of presidential and parliamentary systems is not necessarily the same, while voting systems can also influence the decisions taken by the government and the legislature. It is these specific effects that are tested in this paper and which represent its main contribution. For this reason we show results in Table 3 
for the models in which institutional and electoral rules were considered in Democratic countries. ${ }^{15}$

(Insert table 3 around here)

Results for this analysis are reported in Table 3. As we did before, we display different specifications according to the use of clusters at country level and the use of time trend or year dummies. ${ }^{16}$

On one hand our results show that Presidential systems are associated with a larger military spending than parliamentary systems. The magnitude of this effect can be estimated taking into account the binary nature of our regressor and the log-linearity of the model, which implies computing $100 *\left(\mathrm{e}^{0.26}-1\right) .{ }^{17}$ As a result, presidential systems are estimated to increase our dependent variable in about $30 \%$. Evaluated at the mean level of military spending in democracies $(2.01 \%)$, this implies a 0.63 more of military spending over GDP. On the other, we find that majoritarian rule (or majority electoral system) has a positive impact on military spending. The magnitude of this effect is less important on our dependent variable, being $8 \%$ higher than that of proportional electoral rules. Evaluated at the mean value of military spending in democracies we find that the increase in the percentage of military spending over GDP is about 0.2. However, the interaction of presidential systems with majority rule is associated with less military expenditure.

Considering that defense spending is a public good, our results appear to be partially inconsistent with the predictions of Persson and Tabellini (1999) and PRT (2000). For instance, the positive correlation between our "Pres" variable and military expenditure rejects

\footnotetext{
${ }^{15}$ Results for the same models applied to the full sample including autocracies and democracies are consistent with the results applied to democracies alone because there are few additional observations with valid values for institutional democratic variables in the case of autocracies. Therefore the sample size is very similar and the weight of democracies is still very high, leading to very similar results.

${ }^{16}$ Note that we do not attempt to estimate our model with a panel data with fixed effects procedure because all variables introduced in this extended model are institutional variables without variation over time, a necessary condition for the within groups estimator.

${ }^{17}$ See Van Garderen and Shah (2002).
} 
the claim that there is an under provision of public goods in presidential democracies. Or, at least, there is no such under provision in defense according to our results.

More interesting is the result linked to the variable "Pres*Major", formed by the interaction of the "Pres" variable with the "Majoritarian" variable, which takes a value of 1 when the political system is presidential and the voting rule is majoritarian and 0 otherwise. The variable appears to be negative and statistically significant.

The "Concentration" variable, which is a Herfindahl index of the concentration of political parties in the parliament, does not appear to be statistically significant in any specification considered. The remaining variables presented consistent results according to the first stage estimation.

Regarding continental fixed effects and time variables results are consistent with the model applied to the full sample. Therefore, the decrease in military spending as an average seems to exist since mid 90's some years after the end of the cold war.

\subsection{Implications of results for the literature}

There are several possible explanations for these empirical findings that contradict, to some extent, existing theoretical literature. First, the model in PRT (2000) considers that the voters in each district compete with each other for governmental redistribution of resources. This means voters from different districts are considered as never holding common interests. Nevertheless, a minimum level of defense spending might be considered as being in the best interests of each voter, regardless of the district in which they are resident. Thus, a framework in which districts have conflicting interests does not seem to be appropriate for understanding the determinants of military expenditure.

Second, other characteristics of presidential systems are not captured by PRT (2000). Linz (1990) argues that presidential democracies are more unstable and prone to conflict than 
parliamentary systems owing to their lack of flexibility and the dual legitimacy that belongs to both the parliament and the president. According to Linz, the military can play a leading role in presidential democracies since, at times, they act as a leveraging power. If this were the case and the military were capable of exerting this influence, this might be reflected in higher defense burdens.

Reynal-Querol (2005) shows that presidential democracies are more prone to civil war, because they are less inclusive than parliamentary systems. This and the other features of each system are not, however, formalized by PRT (2000). And it would seem, moreover, that the instability associated with presidential democracies might serve to increase defense expenditure. Indeed, Furthermore, military spending could not be a public good for the population, but a rather private good for the ruling class (Besley \& Person, 2008, 2010); therefore, military spending could be used even in a presidential democracy to increase the probability of reelection.

In conclusion, therefore, the institutional variables that are able to identify the different dimensions of democracies appear to be significant. These variables, however, have never previously been taken into account as determinants of defense burdens, but it would seem that there are characteristics of political systems above and beyond measures of democracy/autocracy that determine budget expenditure decisions, including that of defense. However, the published theoretical models do not capture these dimensions that seem to have an impact on military spending. Thus, more theoretical research needs to be conducted so as to understand better the institutional determinants of military expenditure.

\section{Concluding remarks}

This paper seeks to contribute to the literature by including institutional variables in its empirical analysis of the determinants of military spending. By so doing, we are able to take 
into account the effects of form of government, electoral systems, concentration of the parliamentary parties, and ideology on the defense burden.

A total of 157 countries were considered for this study between 1988 and 2006. From our empirical analysis, we can infer that countries with a presidential democracy spend more on defense than their parliamentary counterparts. Moreover, countries operating majoritarian voting systems spend more than countries operating proportional representation. This effect of the institutional design of each country is of interest since the defense burden is of great importance in post-conflict situations as it could curtail growth in corrupt and poor countries. Therefore, we can conclude that there are certain structural characteristics of a political system that are of importance for reducing the risk of conflict and cutting military spending. Only the interaction of presidential systems with majoritarian rule appears to diminish military spending.

The regressions conducted here suggest that democratic institutions do not have the same impact on all public goods, in contrast to predictions in the literature. Thus, presidential democracies may well spend more heavily on defense while other public goods face underprovisions. Several factors account for our results, of which two are particularly influential. First, the lack of flexibility as well as the dual legitimacy that characterizes presidential systems, which give the army a certain leveraging power, can result in higher military expenditure. Second, the instability associated with presidential systems might also explain these results. Thus, these characteristics of presidential democracies might explain the different patterns of behavior observed in military expenditure compared to those recorded for other public goods.

All in all, we have shown that a consideration of institutional variables within the analysis of military spending can provide new insights and empirical evidence, and thereby enhance our understanding of this issue. 


\section{References}

Beck, Thorsten., Clarke, George., Groff, Alberto., Keefer, Philip., and Walsh, Patrick. (2001) New tools in comparative political economy: The Database of Political Institutions, World Bank Economic Review, 15, 165-176,

Besley, Timothy. and Torsten Persson (2008a) War and State Capacity. Journal of the European Economics Association, 6 (2-3), 522-530.

Besley, Timothy. and Torsten Persson (2008b) The incidence of civil war: theory and evidence. National Bureau of Economic Research, Working Papers 14585.

Besley, Timothy. and Torsten Persson (2009) Repression or Civil War. American Economic Review, 99 (2), 292-297.

Besley, Timothy. and Torsten Persson (2010) State Capacity, Conflict and Development. Econometrica, 78 (1), 1-34,

Blattman, Christopher. and Miguel, Edward (forthcoming). Civil War. Journal of Economic Literature. Forthcoming.

Bove, Vincenzo, and Brauner, Jennifer (2011) The Demand for Military Expenditure in Authoritarian Regimes. Working Paper, Birbeck, University of London.

Clifton Morgan, T. and Bickers. Kenneth N. (1992) Domestic Discontent and the External Use of Force, Journal of Conflict Resolution, 36, 25-52.

Collier, Paul, and Hoeffler, Anke (1998) On economic causes of civil war, Oxford Economic Papers. 50, 563-573.

Collier, Paul, and Hoeffler, Anke (2002) On the Incidence of Civil War in Africa, Journal of Conflict Resolution, 46, 13-28.

Collier, Paul, and Hoeffler, Anke (2004) Greed and grievance in civil war, Oxford Economic Papers, $56,563-595$.

Collier, Paul, and Hoeffler, Anke (2006) Military expenditure in post-conflict societies, Economics of Governance, 7, 89-107.

Collier, Paul, and Hoeffler, Anke (2007) Unintended Consequences: Does Aid Promote Arms Races?, Oxford Bulletin of Economics and Statistics, 69, 1-27.

Collier, Paul, and Dominic Rohner (2008) Democracy, Development and Conflict. Journal of the European Economics Association, 6 (2-3), 531-540.

Djankov, Simeon, and Reynal-Querol, Marta (forthcoming) Poverty and Civil War: Revisiting the evidence, Review of Economics and Statistics, Forthcoming.

Dunne, John P. and Perlo-Freeman, Samuel (2003a) The demand for military spending in developing countries: a dynamic panel analysis, Defense and Peace Economics, 14, 461-474.

Dunne, John P. and Perlo-Freeman, Samuel (2003b) The demand for military spending in developing countries, International Review of Applied Economics, 17, 23-48. 
Dunne, John P., Perlo-Freeman, Samuel, and Smith, Ronald P. (2008) The demand for military expenditure in developing countries: hostility versus capability, Defense and Peace Economics, 19, 293-302.

Dunne, John P.; Smith, Ronald P. and Willenbockel, Dirk (2005) Models of Military Expenditure and Growth: A Critical Review, Defense and Peace Economics, 16, 449-461.

Gadea, Maria Dolores, Pardos, Eva, and Pérez-Fornies, Claudia (2004) A long-run analysis of defense spending in the NATO countries (1960-99), Defense and Peace Economics, 15, 231-249.

Grossman, Herschel I. (1991) A General Equilibrium Model of Insurrections, American Economic Review, 81, 912-921.

Harbom, Lotta, and Wallensteen, Peter (2007) Armed Conflict, 1989-2006, Journal of Peace Research, 44 623-634.

Henderson, Conway W. (1991) Conditions Affecting the Use of Political Repression, Journal of Conflict Resolution, 35, 120-142.

Humphreys, Macartan, and Weinstein, Jeremy M. (2007) Demobilization and Reintegration, Journal of Conflict Resolution, 51, 531-567.

Jaggers, Keith, and Gurr, Ted R. (1995) Tracking Democracy's Third Wave with the Polity IV Data, Journal of Peace Research, 32, 469-82.

James, Patrick, and Oneal, John R. (1991) The Influence of Domestic and International Politics on the President's Use of Force, Journal of Conflict Resolution, 35, 307-332.

Linz, Juan J. (1990) The Perils of Presidentialism, Journal of Democracy, 1, 51-69.

Linz, Juan J. (1994) Democracia presidencial o parlamentaria. ¿Qué diferencia implica?” In Las crisis del presidencialismo. 1. Perspectivas comparadas, ed. J.J. Linz and A.Valenzuela, Alianza Editorial, Madrid, pp. 25-143.

Maoz, Zeev, and Abdolali, Nasrin (1989) Regime Types and International Conflict, 1816-1976, Journal of Conflict Resolution, 33, 3-35.

Majeski, Stephen J. and Jones, David L. (1981) Arms Race Modeling: Causality Analysis and Model Specification, Journal of Conflict Resolution, 25, 259-288.

Miguel, Edward, Satyanath, Shanker, and Sergenti, Ernest (2004) Economic Shocks and Civil Conflict: An Instrumental Variables Approach, Journal of Political Economy, 112, 725-753.

Nikolaidou, Eftychia (2008) The demand for military expenditure: evidence from the EU15 (19612005), Defense and Peace Economics, 19, 273-292.

Nordhaus, William; Oneal, John R. and Russett, Bruce (2009) The Effects of the Security Environment on Military Expenditures: Pooled Analysis of 165 Countries, 1950-2000. Cowles Foundation Paper No 1707, Yale University.

North, Douglas C. (1990) Institutions, institutional change and economic performance, Cambridge University Press, Cambridge, UK. 
Persson, Torsten, Roland, Gérard, and Tabellini, Guido (1997) Separation of Powers and Political Accountability, Quarterly Journal of Economics, 112, 1163-1202.

Persson, Torsten, Roland, Gérard, and Tabellini, Guido (2000) Comparative Politics and Public Finance, Journal of Political Economy, 108, 1121-1161.

Persson, Torsten, and Tabellini, Guido (1999) The Size and Scope of Government: Comparative Politics with Rational Politicians, European Economic Review, 43, 699-735.

Persson, Torsten, and Tabellini, Guido (2003) The Economic Effects of Constitutions, The MIT Press, Cambridge, MA.

Reynal-Querol, Marta (2005) Does democracy preempt civil wars?" European Journal of Political Economy, 21, 445-465

Richardson, Lewis F. (1960) Arms and Insecurity. Homewood, Pittsburgh, PA.

Rosh, Robert M. (1988) Third World Militarization. Security Webs and the States they Ensnare, Journal of Conflict Resolution, 32, 671-698.

Stålenheim, Petter, Perdomo, Catalina, and Sköns, Elisabeth (2008) Military Expenditure, SIPRI Yearbook 2008. Oxford University Press: Oxford, pp. 175-206.

Yildirim, Julide, and Sezgin, Selami (2005) Democracy and Military expenditure: A Cross-Country Evidence, Transition Studies Review, 12, 93-100.

Van Garderen, Kees J. and Shah, Chandra (2000) Exact interpretation of dummy variables in semilogarithmic equations", Econometrics Journal 5, 149-159. 
Table 1. Variable definition, data sources and expected effects.

\begin{tabular}{|c|c|c|c|}
\hline Variable & Definition & Sources & Hypothesis \\
\hline $\begin{array}{l}\text { Ln military } \\
\text { expenditure }\end{array}$ & $\begin{array}{l}\text { Data for military spending as a percentage of GDP, from } \\
1988 \text { to } 2007 \text {. }\end{array}$ & $\begin{array}{l}\text { SIPRI (Stockholm International Peace } \\
\text { Research Institute) } \\
\text { (http://www.sipri.org/databases/milex). }\end{array}$ & - \\
\hline Civil war & $\begin{array}{l}\text { A dummy variable that takes a value of } 1 \text { if there is a } \\
\text { conflict, with a minimum of } 25 \text { battle-related deaths per } \\
\text { year and per dyad between the government of a state and at } \\
\text { least one opposition group without intervention from other } \\
\text { states. }\end{array}$ & $\begin{array}{l}\text { PRIO (Peace Research Institute of } \\
\text { Oslo http://www.prio.no/). }\end{array}$ & Positive. \\
\hline Previous war & $\begin{array}{l}\text { A dummy variable taking value of } 1 \text { if the country has been } \\
\text { involved in a war during the period } 1978-87 \text {. }\end{array}$ & $\begin{array}{l}\text { PRIO (Peace Research Institute of } \\
\text { Oslo http://www.prio.no/). }\end{array}$ & Positive. \\
\hline Emulation & $\begin{array}{l}\text { For country } i \text {, the sum of the defense spending of its } \\
\text { neighboring countries is divided by the sum of national } \\
\text { income of all these neighboring countries. National income } \\
\text { is the real PPP-adjusted GDP (base year is 2005). }\end{array}$ & $\begin{array}{l}\text { SIPRI and World Economic Outlook } \\
\text { (http://www.imf.org/external/pubs/ft/w } \\
\text { eo/2009/01/weodata/index.aspx). }\end{array}$ & Positive. \\
\hline Alliance & $\begin{array}{l}\text { A dummy variable that takes a value of } 1 \text { for the years } \\
\text { when the country belongs to a military treaty such as } \\
\text { NATO and the Warsaw Pact. Since the Warsaw Pact was } \\
\text { dissolved in 1991, all countries that were part of this } \\
\text { alliance score } 0 \text { from } 1992 \text { onwards. }\end{array}$ & Authors' own. & Ambiguous. \\
\hline Ln population & The logarithm of the total population of each country. & World Development Indicators. & Negative. \\
\hline $\begin{array}{l}\text { Ln GDP per } \\
\text { capita }\end{array}$ & $\begin{array}{l}\text { Measured as real PPP-adjusted GDP per capita (the base } \\
\text { year is 2005). }\end{array}$ & World Economic Outlook. & Positive. \\
\hline Democracy & $\begin{array}{l}\text { The difference between a country's democracy and } \\
\text { autocracy scores (See note). }\end{array}$ & $\begin{array}{l}\text { Data source is Polity IV (Jaggers \& } \\
\text { Gurr, 1995). }\end{array}$ & Negative. \\
\hline Freedom & $\begin{array}{l}\text { Political and Civil rights scores from Freedom in the World } \\
\text { survey. A range from } 1 \text { to } 7 \text {, in which } 1 \text { is maximum } \\
\text { freedom and } 7 \text { is the minimum score of freedom. }\end{array}$ & Freedom House. Freedomhouse.org & Negative. \\
\hline Pres & $\begin{array}{l}\text { A dummy variable that takes a value of } 1 \text { if the democracy } \\
\text { is presidential and } 0 \text { if it is parliamentary. A country is } \\
\text { considered to be a democracy when the Polity IV score of } \\
\text { democracy is higher than its autocracy score (see } \\
\text { Democracy). }\end{array}$ & $\begin{array}{l}\text { Database of Political Institutions and } \\
\text { authors' own. It is constructed from } \\
\text { "system". All assembly-elected } \\
\text { president democracies are considered } \\
\text { parliamentarian. }\end{array}$ & $\begin{array}{l}\text { Positive } \\
\text { (PRT, 2000). } \\
\text { Negative } \\
\text { (Linz, } 1990 \\
\text { 1994). }\end{array}$ \\
\hline Majoritarian & $\begin{array}{l}\text { A dummy variable that takes a value of } 1 \text { if there is a } \\
\text { majority electoral system. }\end{array}$ & Database of Political Institutions. & $\begin{array}{l}\begin{array}{l}\text { Negative } \\
\text { (PRT, 2000). }\end{array} \\
\end{array}$ \\
\hline Pres*Major & $\begin{array}{l}\text { A dummy variable that takes a value of } 1 \text { when the political } \\
\text { system is presidential and majoritarian and } 0 \text { otherwise. }\end{array}$ & Database of Political Institutions. & $\begin{array}{l}\text { Negative, } \\
\text { (PRT, 2000). }\end{array}$ \\
\hline Concentration & $\begin{array}{l}\text { The sum of the squared seat shares of all parties in the } \\
\text { parliament. }\end{array}$ & Database of Political Institutions. & Positive. \\
\hline Trend & $\begin{array}{l}\text { A variable that captures the effects of time. It takes a value } \\
\text { of one for the first year in the sample, 1988, and it increases } \\
\text { by one for each passing year. }\end{array}$ & Authors' own. & Negative. \\
\hline Africa & $\begin{array}{l}\text { A dummy variable that takes a value of } 1 \text { for all countries } \\
\text { on the African continent and } 0 \text { otherwise. }\end{array}$ & Authors' own. & $\begin{array}{l}\text { No } \\
\text { references. }\end{array}$ \\
\hline Europe & $\begin{array}{l}\text { A dummy variable that takes a value of } 1 \text { for all countries } \\
\text { on the European continent and } 0 \text { otherwise. }\end{array}$ & Authors' own. & $\begin{array}{l}\text { No } \\
\text { references. }\end{array}$ \\
\hline Asia & $\begin{array}{l}\text { A dummy variable that takes a value of } 1 \text { for all countries } \\
\text { on the Asian continent and } 0 \text { otherwise. }\end{array}$ & Authors' own. & $\begin{array}{l}\text { No } \\
\text { references. }\end{array}$ \\
\hline
\end{tabular}

Note: the scores for the Democracy variable are constructed by considering the competitiveness of political participation, the regulation of political participation, the competitiveness of executive recruitment, the openness of executive recruitment and the constraints on the chief executive. Each score ranges from 0 to 10. Therefore, "Democracy" ranges between -10 (perfect autocracy) and 10 (perfect democracy) 
Table 2. Least squares estimates for models on government military expenditure.

\begin{tabular}{|c|c|c|c|c|c|c|}
\hline COVARIATES & $\begin{array}{l}\text { Pooled } \\
\text { (1) }\end{array}$ & $\begin{array}{l}\text { Pooled-Clustered } \\
\text { (2) }\end{array}$ & $\begin{array}{l}\text { Pooled- } \\
\text { Clustered } \\
\text { (3) }\end{array}$ & $\begin{array}{c}\text { Pooled-Clustered } \\
\text { (4) }\end{array}$ & $\begin{array}{l}\text { Panel Data } \\
\text { Fixed } \\
\text { Effects } \\
(5)\end{array}$ & $\begin{array}{c}\text { OLS Cross Section } \\
\text { (Mean of all years) } \\
\text { (6) }\end{array}$ \\
\hline Civilwar & $\begin{array}{c}0.3482 * * * \\
(0.0449)\end{array}$ & $\begin{array}{c}0.3482 * * * \\
(0.1199)\end{array}$ & $\begin{array}{c}0.3139 * * \\
(0.1282)\end{array}$ & $\begin{array}{c}0.3121 * * \\
(0.1291)\end{array}$ & $\begin{array}{c}0.1474 * * \\
(0.0607)\end{array}$ & $\begin{array}{c}0.4761 * * \\
(0.2162)\end{array}$ \\
\hline Previouswar & $\begin{array}{c}0.0210 \\
(0.0377)\end{array}$ & $\begin{array}{c}0.0210 \\
(0.1324)\end{array}$ & $\begin{array}{c}0.0053 \\
(0.1327)\end{array}$ & $\begin{array}{c}0.0058 \\
(0.1332)\end{array}$ & - & $\begin{array}{c}0.1026 \\
(0.1350)\end{array}$ \\
\hline Lemulation & $\begin{array}{c}0.0645 * * \\
(0.0274)\end{array}$ & $\begin{array}{c}0.0645 \\
(0.0323)\end{array}$ & $\begin{array}{c}0.0651 * * \\
(0.0316)\end{array}$ & $\begin{array}{c}0.0655^{* *} * \\
(0.0316)\end{array}$ & $\begin{array}{c}2.90 \mathrm{e}-16 \\
(7.47 \mathrm{e}-16)\end{array}$ & $\begin{array}{c}0.0852 \\
(0.0536)\end{array}$ \\
\hline Alliance & $\begin{array}{c}0.3286 * * * \\
(0.0436)\end{array}$ & $\begin{array}{c}0.3286 * * * \\
(0.1466)\end{array}$ & $\begin{array}{l}0.3007 * \\
(0.1587)\end{array}$ & $\begin{array}{l}0.3028 * \\
(0.1617)\end{array}$ & $\begin{array}{c}0.2292^{* *} \\
(0.0898)\end{array}$ & $\begin{array}{c}0.2058 \\
(0.2103)\end{array}$ \\
\hline Lpop & $\begin{array}{c}-0.0554 * * * \\
(-0.0118)\end{array}$ & $\begin{array}{c}-0.0554 \\
(.0415)\end{array}$ & $\begin{array}{l}-0.0438 \\
(0.0469)\end{array}$ & $\begin{array}{l}-0.0436 \\
(0.0472)\end{array}$ & $\begin{array}{l}-0.1645 \\
(0.2842)\end{array}$ & $\begin{array}{l}-0.0570 \\
(0.0474)\end{array}$ \\
\hline Lgdppc & $\begin{array}{c}0.0518 * * * \\
(0.0109)\end{array}$ & $\begin{array}{l}0.0518 \\
(.0385)\end{array}$ & $\begin{array}{l}0.0659 * \\
(0.0375)\end{array}$ & $\begin{array}{l}0.0659 * \\
(0.0376)\end{array}$ & $\begin{array}{c}0.0602 * * \\
(0.0266)\end{array}$ & $\begin{array}{c}0.0894 * * \\
(0.0404)\end{array}$ \\
\hline Democracy & $\begin{array}{c}-0.2745^{* * * *} \\
(0.0374)\end{array}$ & $\begin{array}{c}-0.2745^{* * *} * \\
(.1038)\end{array}$ & - & - & - & - \\
\hline Freedom & - & - & $\begin{array}{c}0.0887 * * * \\
(0.0293)\end{array}$ & $\begin{array}{c}0.0893 * * * \\
(0.0295)\end{array}$ & $\begin{array}{c}0.0464 * * * \\
(0.0170)\end{array}$ & $\begin{array}{c}0.0995 * * \\
(0.0456)\end{array}$ \\
\hline Trend & $\begin{array}{c}-0.0138 * * * \\
(0.0030)\end{array}$ & $\begin{array}{c}-0.0138 * * * \\
(0.0048)\end{array}$ & $\begin{array}{c}-0.0149 * * * \\
(0.0043)\end{array}$ & - & $\begin{array}{c}-0.0119 * * \\
(0.0055)\end{array}$ & - \\
\hline Africa & $\begin{array}{c}0.2664 * * * \\
(.0480)\end{array}$ & $\begin{array}{l}0.2664 * \\
(0.1472)\end{array}$ & $\begin{array}{l}0.2626^{*} \\
(0.1529)\end{array}$ & $\begin{array}{l}0.2619 * \\
(0.1536)\end{array}$ & - & $\begin{array}{c}0.2381 \\
(0.1716)\end{array}$ \\
\hline Europe & $\begin{array}{c}0.0464 \\
(0.0481)\end{array}$ & $\begin{array}{l}0.0464 \\
(.1701)\end{array}$ & $\begin{array}{c}0.0898 \\
(0.1738)\end{array}$ & $\begin{array}{c}0.0903 \\
(0.1745)\end{array}$ & - & $\begin{array}{c}0.1086 \\
(0.1895)\end{array}$ \\
\hline Asia & $\begin{array}{c}0.5873 * * * \\
(0.0540)\end{array}$ & $\begin{array}{c}0.5873 * * * \\
(0.1725)\end{array}$ & $\begin{array}{c}0.6046 * * * \\
(0.1877)\end{array}$ & $\begin{array}{c}0.6043 * * * \\
(0.1888)\end{array}$ & - & $\begin{array}{c}0.4499 * * \\
(0.2077)\end{array}$ \\
\hline Constant & $\begin{array}{c}29.05 * * * \\
(6.003)\end{array}$ & $\begin{array}{c}29.05 * * * \\
(9.427)\end{array}$ & $\begin{array}{c}0.7033 \\
(0.7938)\end{array}$ & $\begin{array}{c}0.6505 \\
(0.7937)\end{array}$ & $\begin{array}{c}3.6917 \\
(4.5562)\end{array}$ & $\begin{array}{c}0.5732 \\
(0.8602)\end{array}$ \\
\hline Dummy years (signif.) & - & - & - & $\begin{array}{c}1996-1997(-)^{*} \\
1999-2001(-)^{* *} \\
2003-2006(-)^{* * *}\end{array}$ & - & - \\
\hline Year Dummies & No & No & No & Yes & No & No \\
\hline Clusters (country) & No & Yes & Yes & Yes & Yes & No \\
\hline $\begin{array}{l}\text { Observations } \\
\text { R-squared } \\
\text { F-test (Joint. Sign.) }\end{array}$ & $\begin{array}{c}2081 \\
0.25 \\
50.08 * * *\end{array}$ & $\begin{array}{c}2081 \\
0.25 \\
7.11 * * *\end{array}$ & $\begin{array}{c}2081 \\
0.26 \\
8.27 * * *\end{array}$ & $\begin{array}{c}2081 \\
0.28 \\
5.26 * * *\end{array}$ & $\begin{array}{c}2081 \\
0.15 \\
4.42 * * *\end{array}$ & $\begin{array}{c}157 \\
0.29 \\
4.30 * * *\end{array}$ \\
\hline Mean VIF & 1.77 & 1.77 & 1.78 & 2.16 & 1.66 & 1.95 \\
\hline
\end{tabular}

Standard errors are reported in parentheses allowing for clustering by country for models $2,3,4$ and 5 . Where clusters are not used, Huber-White standard errors are presented. These models are model 1 and model 6. $* * * \mathrm{p}<0.01, * * \mathrm{p}<0.05, * \mathrm{p}<0.1$ 
Table 3. Least squares estimates for pooled models on democratic government military expenditure.

\begin{tabular}{|c|c|c|c|c|c|}
\hline COVARIATES & $\begin{array}{c}\text { Pooled } \\
\text { OLS } \\
(7) \\
\end{array}$ & $\begin{array}{c}\text { Pooled OLS- } \\
\text { Clustered } \\
(8) \\
\end{array}$ & $\begin{array}{c}\text { Pooled OLS } \\
(9) \\
\end{array}$ & $\begin{array}{c}\text { Pooled OLS- } \\
\text { Clustered } \\
(10) \\
\end{array}$ & $\begin{array}{c}\text { OLS Cross Section } \\
\text { (Mean of all years) } \\
(11)\end{array}$ \\
\hline Civilwar & $\begin{array}{c}0.4467 * * * \\
(0.0734)\end{array}$ & $\begin{array}{c}0.4467 * * \\
(0.1745)\end{array}$ & $\begin{array}{c}0.4457 * * * \\
(0.0734)\end{array}$ & $\begin{array}{c}0.4457 * * * \\
(.1748)\end{array}$ & $\begin{array}{c}0.7698 * * * \\
(0.2298)\end{array}$ \\
\hline Previouswar & $\begin{array}{l}-0.0544 \\
(0.0530)\end{array}$ & $\begin{array}{l}-0.0544 \\
(0.1634)\end{array}$ & $\begin{array}{l}-0.0545 \\
(0.0526)\end{array}$ & $\begin{array}{l}-0.0545 \\
(0.1634)\end{array}$ & $\begin{array}{c}0.0640 \\
(0.1687)\end{array}$ \\
\hline Lemulation & $\begin{array}{c}0.0084 \\
(0.0074)\end{array}$ & $\begin{array}{c}0.0084 \\
(0.0131)\end{array}$ & $\begin{array}{c}0.0086 \\
(0.0076)\end{array}$ & $\begin{array}{c}0.0086 \\
(0.0135)\end{array}$ & $\begin{array}{c}0.0569 \\
(0.0533)\end{array}$ \\
\hline Alliance & $\begin{array}{c}0.2629 * * * \\
(0.0407)\end{array}$ & $\begin{array}{l}0.2629 * \\
(0.1405)\end{array}$ & $\begin{array}{c}0.2605 * * * \\
(0.0416)\end{array}$ & $\begin{array}{c}0.2605 * * * \\
(0.1440)\end{array}$ & $\begin{array}{l}0.3575^{*} \\
(0.1999)\end{array}$ \\
\hline Lpop & $\begin{array}{c}0.0113 \\
(0.0156)\end{array}$ & $\begin{array}{c}0.0113 \\
(0.0517)\end{array}$ & $\begin{array}{c}0.0113 \\
(0.0157)\end{array}$ & $\begin{array}{c}0.0113 \\
(0.0520)\end{array}$ & $\begin{array}{l}-0.0484 \\
(0.0569)\end{array}$ \\
\hline Lgdppc & $\begin{array}{c}0.1207 * * * \\
(0.0181)\end{array}$ & $\begin{array}{l}0.1207 * \\
(0.0620)\end{array}$ & $\begin{array}{c}0.1212 * * * \\
(0.0181)\end{array}$ & $\begin{array}{c}0.1212 * * * \\
(0.0624)\end{array}$ & $\begin{array}{c}0.0530 \\
(0.0482)\end{array}$ \\
\hline Pres & $\begin{array}{c}0.2607 * * * \\
(0.0599)\end{array}$ & $\begin{array}{l}0.2607 * \\
(0.1554)\end{array}$ & $\begin{array}{c}0.2695 * * * \\
(0.0601)\end{array}$ & $\begin{array}{c}0.2695 * * * \\
(0.2695)\end{array}$ & $\begin{array}{l}0.3110^{*} \\
(0.1792)\end{array}$ \\
\hline Majoritarian & $\begin{array}{l}0.0838 * \\
(0.0438)\end{array}$ & $\begin{array}{c}0.0838 \\
(0.1460)\end{array}$ & $\begin{array}{c}0.0874 * * \\
(0.0441)\end{array}$ & $\begin{array}{c}0.0874 * * \\
(0.0874)\end{array}$ & $\begin{array}{c}0.2375 \\
(0.1556)\end{array}$ \\
\hline Pres*Major & $\begin{array}{c}-0.1957 * * * \\
(0.0685)\end{array}$ & $\begin{array}{l}-0.1957 \\
(0.2061)\end{array}$ & $\begin{array}{c}-0.2017 * * * \\
(0.0688)\end{array}$ & $\begin{array}{c}-0.2017 * * * \\
(-0.2017)\end{array}$ & $\begin{array}{l}-0.3833 * \\
(0.2024)\end{array}$ \\
\hline Concentration & $\begin{array}{c}0.0633 \\
(0.0719)\end{array}$ & $\begin{array}{c}0.0633 \\
(0.1862)\end{array}$ & $\begin{array}{c}0.0578 \\
(0.0723)\end{array}$ & $\begin{array}{c}0.0578 \\
(0.0578)\end{array}$ & $\begin{array}{l}-0.1527 \\
(0.3074)\end{array}$ \\
\hline Trend & $\begin{array}{c}-0.0252 * * * \\
(0.0032)\end{array}$ & $\begin{array}{c}-0.0252 * * * \\
(0.0055)\end{array}$ & - & - & - \\
\hline Africa & $\begin{array}{c}0.4528 * * * \\
(0.0646)\end{array}$ & $\begin{array}{c}0.4528 * * \\
(0.1903)\end{array}$ & $\begin{array}{c}0.4553 * * * \\
(0.0647)\end{array}$ & $\begin{array}{c}0.4553 * * * \\
(0.4553)\end{array}$ & $\begin{array}{l}0.2964 * \\
(0.1768)\end{array}$ \\
\hline Europe & $\begin{array}{c}0.1718 * * * \\
(0.0565)\end{array}$ & $\begin{array}{c}0.1718 \\
(0.1860)\end{array}$ & $\begin{array}{c}0.1785 * * * \\
(0.0562)\end{array}$ & $\begin{array}{c}0.1785^{* * * *} \\
(0.1785)\end{array}$ & $\begin{array}{c}0.2116 \\
(0.2398)\end{array}$ \\
\hline Asia & $\begin{array}{c}0.5986 * * * \\
(0.0742)\end{array}$ & $\begin{array}{c}0.5986 * * \\
(0.2274)\end{array}$ & $\begin{array}{c}0.6028 * * * \\
(0.0745)\end{array}$ & $\begin{array}{c}0.6028 * * * \\
(0.6028)\end{array}$ & $\begin{array}{l}0.4051 * \\
(0.2268)\end{array}$ \\
\hline Dummy years (signif) & - & - & $\begin{array}{c}1995-1998(-)^{*} \\
1999-2006(-)^{* *}\end{array}$ & $\begin{array}{c}1995(-)^{* *} \\
1996-2006(-)^{* * *}\end{array}$ & - \\
\hline Year Dummies & No & No & Yes & Yes & No \\
\hline Clusters (country) & No & Yes & No & Yes & No \\
\hline $\begin{array}{l}\text { Observations } \\
\text { R-squared } \\
\text { F-test (Joint Sign.) }\end{array}$ & $\begin{array}{c}1121 \\
0.24 \\
25.41 * * * \\
\end{array}$ & $\begin{array}{c}1121 \\
0.24 \\
3 . .38 * * * \\
\end{array}$ & $\begin{array}{c}1121 \\
0.25 \\
11.77 * * * \\
\end{array}$ & $\begin{array}{c}1121 \\
0.025 \\
3.11 * * * \\
\end{array}$ & $\begin{array}{c}91 \\
0.29 \\
2.63 * * * \\
\end{array}$ \\
\hline Mean VIF & 1.76 & 2.04 & 2.67 & 2.67 & 2.25 \\
\hline
\end{tabular}

Standard errors are reported in parentheses allowing for clustering by country for models 8 and 10 . Where clustering is not used, Huber-White standard errors are presented. These models are models 7, 9 and 11. $* * * \mathrm{p}<0.01, * * \mathrm{p}<0.05, * \mathrm{p}<0.1$. 


\section{Appendix A}

Correlation matrix

\begin{tabular}{|c|c|c|c|c|c|c|c|c|c|c|c|c|c|c|c|c|}
\hline & $\frac{\bar{z}}{3}$ & 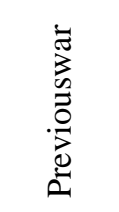 & 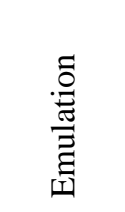 & $\begin{array}{l}\stackrel{\Xi}{\Xi} \\
\stackrel{\Xi}{\Xi} \\
\end{array}$ & $\begin{array}{l}\stackrel{0}{2} \\
\stackrel{2}{a}\end{array}$ & $\begin{array}{l}0 \\
\frac{0}{2} \\
\frac{0}{0} \\
\end{array}$ & 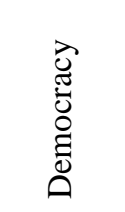 & 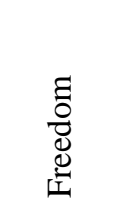 & $\stackrel{0}{0}$ & 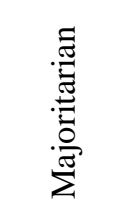 & 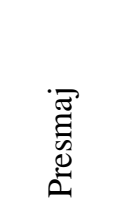 & 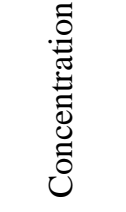 & $\begin{array}{l}\vec{D} \\
\vec{D} \\
\vec{E}\end{array}$ & $: e^{\mathscr{E}}$ & 苙 & $\frac{\pi}{\frac{\pi}{2}}$ \\
\hline Civilwar & 1 & & & & & & & & & & & & & & & \\
\hline Previouswar & 0.5136 & 1 & & & & & & & & & & & & & & \\
\hline Emulation & -0.0184 & -0.0611 & 1 & & & & & & & & & & & & & \\
\hline Alliance & -0.0927 & 0.0355 & 0.0870 & 1 & & & & & & & & & & & & \\
\hline Lpop & 0.2992 & 0.5025 & -0.1063 & 0.2714 & 1 & & & & & & & & & & & \\
\hline Lgdppc & -0.2166 & -0.1576 & 0.1471 & 0.5597 & 0.0895 & 1 & & & & & & & & & & \\
\hline Democracy & -0.2259 & -0.1676 & 0.1142 & 0.4066 & 0.0454 & 0.7116 & 1 & & & & & & & & & \\
\hline Freedom & 0.2086 & 0.2920 & -0.0334 & -0.3845 & 0.0648 & -0.4696 & -0.8000 & 1 & & & & & & & & \\
\hline Pres & 0.1186 & 0.1716 & -0.0537 & -0.4046 & 0.0384 & -0.4940 & -0.4251 & 0.4357 & 1 & & & & & & & \\
\hline Majoritarian & -0.0723 & 0.0343 & -0.1562 & 0.0098 & 0.2928 & -0.1970 & -0.1057 & 0.3268 & 0.0431 & 1 & & & & & & \\
\hline Pres*Major & -0.0314 & 0.0451 & -0.1246 & -0.2471 & 0.1342 & -0.4201 & -0.3803 & 0.3052 & 0.6558 & 0.5228 & 1 & & & & & \\
\hline Concentration & -0.0607 & 0.1076 & -0.0662 & -0.0939 & -0.1310 & -0.3061 & -0.3032 & -0.0489 & 0.0486 & 0.2821 & 0.0792 & 1 & & & & \\
\hline Trend & -0.1035 & -0.0202 & -0.2198 & -0.0029 & 0.0154 & 0.0572 & -0.0072 & -0.0892 & 0.0772 & 0.0323 & 0.0947 & -0.0796 & 1 & & & \\
\hline Africa & -0.0835 & 0.1160 & -0.0859 & -0.2605 & -0.1633 & -0.4871 & -0.4258 & 0.4028 & 0.1903 & 0.1594 & 0.2688 & 0.4358 & 0.0834 & 1 & & \\
\hline Europe & -0.1982 & -0.2317 & 0.1829 & 0.5580 & -0.0920 & 0.5158 & 0.3905 & -0.4657 & -0.5423 & -0.2736 & -0.3951 & -0.2993 & 0.0133 & -0.3668 & 1 & \\
\hline Asia & 0.5162 & 0.3192 & -0.0758 & -0.2064 & 0.3255 & -0.1696 & -0.0895 & 0.3272 & -0.0230 & 0.1139 & -0.0543 & -0.1006 & -0.0391 & -0.1550 & -0.2906 & 1 \\
\hline
\end{tabular}

